\title{
Niemann-Pick Disease: An Approach for Diagnosis in Adulthood
}

\author{
Bonell Patiño-Escobar ${ }^{1}$, Maria H. Solano ${ }^{1}$, Laura Zarabanda ${ }^{2}$, Claudia P. Casas ${ }^{1}$, Carlos Castro $^{3}$ \\ 1. Hematology, San Jose Hospital - University Foundation of Health Sciences, Bogotá, COL 2. Seedbed of Research \\ Program, San Jose Hospital - University Foundation of Health Sciences, Bogotá, COL 3. Epidemiology and Public \\ Health, San Jose Hospital - University Foundation of Health Sciences, Bogotá, COL
}

Corresponding author: Bonell Patiño-Escobar, bonell32@hotmail.com

\begin{abstract}
Niemann-Pick (NP) disease is a rare, autosomal recessive disorder characterized by visceromegaly and neurological alterations due to the excessive storage of lipids, sphingomyelin, and cholesterol. It commonly affects the child population, and only $6 \%$ of it occurs in the adult population. Type A is classified as the acute form, type $\mathrm{B}$ is the latest and with the best prognosis, and type $\mathrm{C}$ is characterized by neurological alteration. The diagnosis is based on enzymatic tests and genetic sequencing, with the latter being the diagnostic confirmation test. No specific treatment exists for this entity, although some patients with NPC type C may benefit from pharmacological treatment with miglustat.
\end{abstract}

The objective of this paper is to describe the clinical characteristics of a grown patient with Niemann-Pick diagnosis type $\mathrm{B}$.

This article reports the case of a 55-year-old adult patient with a three-year clinical history consisting of splenomegaly and hematological disorders, without neurological symptoms ruling out frequent pathologies. Type B NP disease is diagnosed by a mutation in the sphingomyelin phosphodiesterase 1 (SMPD1) gene. The patient was receiving multidisciplinary support treatment.

Although NP disease is a rare disease according to the literature, it is important to consider this group of disorders as a differential diagnosis, when other more common pathologies have been ruled out in patients with isolated splenomegaly and thrombocytopenia

Received 04/19/2019

Review began 04/27/2019

Review ended 05/21/2019

Published 05/28/2019

๑) Copyright 2019

Patino-Escobar et al. This is an open

access article distributed under the terms

of the Creative Commons Attribution

License CC-BY 3.0., which permits

unrestricted use, distribution, and

reproduction in any medium, provided the original author and source are credited.
Categories: Family/General Practice, Genetics, Internal Medicine

Keywords: niemann-pick disease, type b, lysosomal acid lipase deficiency, rare disease, splenomegaly

\section{Introduction}

Lysosomal storage diseases are characterized by an enzymatic deficiency that involves the main function of lysosomes. Currently, there are 50 different kinds of heritage metabolic diseases [1]. Niemann-Pick (NP) disease, within this group, is an autosomal recessive disease. It is defined as the acid sphingomyelinase enzyme deficiency (SED), producing an alteration in the sphingomyelin and lipids deposits, thus causing a structural and functional change in the cell and viscera tissue [2]. The global prevalence is estimated between four and six cases per 1,000,000 of inhabitants [3] and is more frequent in the ascendant Jewish population. NP is diagnosed in $80 \%$ of cases under the age of 16 years, in $14 \%$ after 20 years of age, and extremely rare in older age, depending on the subtype [4-5].

Albert Niemann reported the first case in 1914, but in 1927, Ludwig Pick presented it as a different disease, marking its histological difference from the Gaucher disease [6]. The NP disease is classified based on organ involvement and enzymatic alteration. There are four sub-types (Types A, B, C, D), depending on the organ involved, age, and symptoms, with subtype B being the most frequent. With regard to enzymatic deficiency, in 1966, it was demonstrated that the acid sphingomyelinase enzyme deficiency (SED) in NP types A and B, but not in NP types C and D. Due to the above-mentioned, the four types of NP disease may be classified into two categories regarding the enzymatic deficiency: Type I is characterized by low acid sphingomyelinase levels seen in NP types A and B. In type II, a defect in low-density lipoprotein (LDL) transportation is seen in $\mathrm{NP}$ types $\mathrm{C}$ and $\mathrm{D}$. The clinical presentation is related to visceromegaly and central nervous system involvement [2]. Diagnosis is based on clinical assessment and diagnostic tests, such as enzymatic quantification, fibroblast culture (Type C), and molecular biology techniques for identification (NPC1, NPC2, and SMPD-1 gene mutation identification). Later, a more specific genetic test should be made in order to obtain a specific diagnosis [7]. Treatment typically targets general symptom management: nevertheless, when there are neuropsychological disturbances, miglustat indication has shown a tendency toward delaying the neuronal degeneration in NP disease type C [2,8-9].

In Colombia, an orphan disease is defined as "A disease chronically debilitating, grave, life-threatening, and include rare diseases such as ultra-orphan diseases and forgotten diseases.” These diseases have more than 


\section{Cureus}

1900 pathologies [10-11], which impact the health system considerably, especially those considered highcost diseases. The identification of such low-frequency diseases becomes a challenge, and hence the importance of recognizing the unique clinical presentation that allows the most appropriate identification and treatment. The main objective of this report is to describe the clinical features of a patient with NP disease type B diagnosed in old age.

\section{Case Presentation}

We present the case of a 55-year-old male patient, who was administered because of a five-year history of abdominal pain localized in the upper left quadrant and hypogastrium, with associated symptoms of weight loss and night sweat that emerged six months prior to his consultation. Looking back into his medical history, the patient had first-grade relatives who suffered pancreatic cancer. He had undergone splenectomy three years before, due to splenomegaly of undetermined cause, with a relief of the symptoms as mentioned above. The patient had no abnormalities on hematology, no visceromegaly, no neurologic disturbances, and no enzymatic alteration on laboratory tests that could lead to a diagnosis of lysosomal storage disease. Further laboratory tests were ordered in order to rule out Gaucher disease vs. Niemann Pick, taking into account the discordance between the enzymatic analysis and the clinical presentation. After a more detailed anamnesis, thrombocytopenia was documented at another institution in the past, which was fluctuant and variable (less than $100.000 \mathrm{cell} / \mathrm{mL}$ ) and a pathology report from the spleen (Table 1).

\begin{tabular}{|c|c|}
\hline Laboratory test & Description / Values \\
\hline $\begin{array}{l}\text { Spleen and lymph node } \\
\text { histopathology } \\
\text { description }\end{array}$ & $\begin{array}{l}\text { Macroscopic: Spleen of } 410 \mathrm{~g} \text { of weight. Microscopic: Wide expansion of red pulp by several } \\
\text { macrophages, with wide and foamy cytoplasm, negative for PAS stain. Few iron deposits. Secondary } \\
\text { splenomegaly due to red pulp occupation by ceroid macrophages and lymph node with paracortical } \\
\text { lymphoid hyperplasia Immunohistochemistry: Negative for neoplasm. }\end{array}$ \\
\hline Bone marrow biopsy & $\begin{array}{l}\text { Cellularity: } 50 \% \text {. Myeloid-erythroid relation: } 1: 1 \text {. Platelets cells: Present. Little platelet cumulus. Erythroid } \\
\text { cells: Normal. Myeloid cells: Mature predominance. Lymphoid cells: } 11 \% \text {, monocytes: } 2 \% \text {, plasmocytes: } \\
1 \% \text {, Blast cells: } 1 \% \text {. Occasional histiocytes. No neoplastic involvement. There are } 10 \% \text { of histiocytes with } \\
\text { features of foamy cells, in an interstitial distribution, which they are negative for PAS staining. Findings } \\
\text { related to NP disease. }\end{array}$ \\
\hline Beta-glycosidase & $16.6 \mathrm{mmol} / \mathrm{mh}(6-9 \mathrm{mmol} / \mathrm{mh})$ \\
\hline Chitotriosidase & $47.8 \mathrm{nmol} / \mathrm{hr} / \mathrm{ml}(<96.7 \mathrm{nmol} / \mathrm{hr} / \mathrm{ml})$ \\
\hline $\begin{array}{l}\text { Infectious: HIV/HCV- } \\
\text { as/FTA-ABS/EBV }\end{array}$ & Negative \\
\hline $\begin{array}{l}\text { Liver function test: } \\
\text { TGO/TGP/Direct } \\
\text { Bilirubin/ indirect } \\
\text { Bilirubin/Albumin }\end{array}$ & $\begin{array}{l}24 \mathrm{U} / \mathrm{L}(15-37 \mathrm{U} / \mathrm{L}) / 35 \mathrm{U} / \mathrm{L}(30-65 \mathrm{U} / \mathrm{L}) / 0.25 \mathrm{mg} / \mathrm{dl}(0.00-0.30 \mathrm{mg} / \mathrm{dl}) / 0.6 \mathrm{mg} / \mathrm{dl}(0.00-0.70 \mathrm{mg} / \mathrm{dl}) / \\
4.48 \mathrm{~g} / \mathrm{dl}(3.4-4.0 \mathrm{~g} / \mathrm{dl})\end{array}$ \\
\hline $\begin{array}{l}\text { Coagulation: } \\
\text { PT/INR/PTT }\end{array}$ & $11.6 \mathrm{seg}(11.3 \mathrm{seg}) / 1.03 \mathrm{seg} / 26.3 \mathrm{seg} .(25.9 \mathrm{seg})$. \\
\hline Karyotype & 46XY (12), No chromosome alterations \\
\hline $\begin{array}{l}\text { Lipid profile: } \\
\text { HDL/LDL/Total } \\
\text { Cholesterol/Triglycerides }\end{array}$ & $30 \mathrm{mg} / \mathrm{dll}$ ( > $40 \mathrm{mg} / \mathrm{dll}) / 112.3 \mathrm{mg} / \mathrm{dll}(<130 \mathrm{mg} / \mathrm{dl}) / 191 \mathrm{mg} / \mathrm{dll}(<190 \mathrm{mg} / \mathrm{Dl}) / 233 \mathrm{mg} / \mathrm{dl}$ (30-200 mg/dl) \\
\hline $\begin{array}{l}\text { Gene mutation } \\
\text { sequencing (centogen) }\end{array}$ & Compatible with NP disease type A/B, caused by mutation detected through SMPD1 gene sequencing \\
\hline $\begin{array}{l}\text { HIV: human immunodeficiency } \\
\text { virus; TGO: glutamic oxalaceti } \\
\text { PTT: partial thromboplastin tin }\end{array}$ & $\begin{array}{l}\text { virus; HCV: hepatitis C virus; FTA-ABS: fluorescent treponemal antibody absorption; EBV: Epstein-Barr } \\
\text { ic transaminase; TGP: glutamic pyruvic transaminase; PT: prothrombin time; INR: international normalized ratio; } \\
\text { ne; LDL: low-density lipoprotein; HDL: high-density lipoprotein }\end{array}$ \\
\hline
\end{tabular}




\section{Cureus}

$\mathrm{mg}$ in a day was ordered for prophylactic management. Furthermore, the patient underwent a neuropsychological assessment to establish a cognitive profile, to identify any failure in self-monitoring, planning, organization, and impulsivity. In accordance with the above, and based on the disease classification, there was no indication of miglustat in this case. Therefore, follow-up and symptom monitoring every six months were decided, including evaluating platelets count and liver and pulmonary test function.
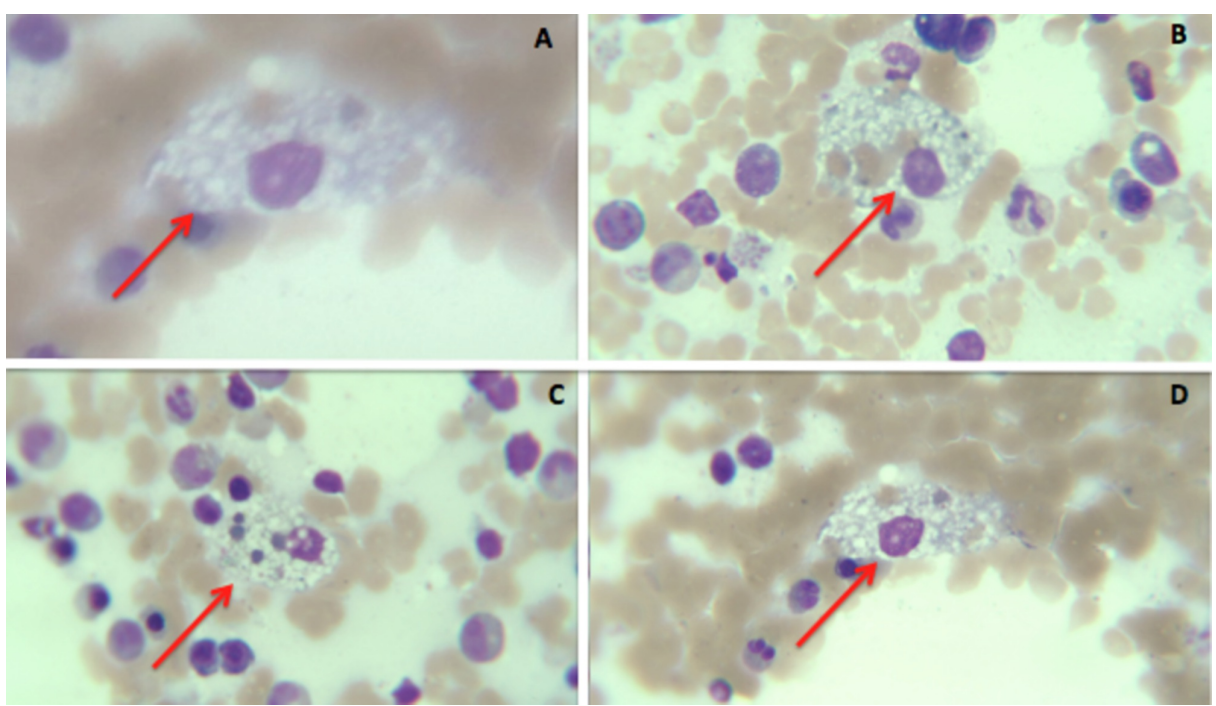

FIGURE 1: Myelogram where the foam cells (Niemann-Pick cells: soapsuds appearance) were found

\section{Discussion}

Orphan diseases are very rare, affecting a small group of people who require highly complex diagnoses. They are life-threatening and cause weakness in the long term [12]. In Colombia, according to SISPRO (Integral Information System of Social Protection) reports, the rate of orphan disease is estimated to be 10 to 28 cases per 100.000 inhabitants [13], making them rare diseases that are less frequently diagnosed in adulthood $[1,14]$. Among those diseases are the lysosomal storage diseases, which originate from a genetic alteration in the enzymes and proteins in charge of macromolecule hydrolysis derived from cellular catabolism.

Ninety-six percent of those diseases have a recessive autosomal heritage origin, such as the NP disease case $[1,12]$. NP types A and B have an incidence of 1 in 250.000 people, whereas the incidence of type $C$ is 1 in every 120,000 living births [15-16]. It is sub-divided depending on the enzymatic alteration type, hence, when acid sphingomyelinase activity (ASM) is null, the enzyme coded by the gene localized on chromosome 11 (p15.1 to p15.4) [17], sphingomyelin phosphodiesterase 1 (SMPD-1), causes a buildup of sphingomyelin, inducing cell death and loss of organ functioning, producing NP disease types A and B [16,18]. In this case, it was possible to determine a relationship between SMPD-1 gene mutation and functional and structural alterations of the spleen, which was clinically evident as splenomegaly in adulthood, a situation that is less frequent due to its presentation being almost always in childhood [7,16]. The clinical presentation may be unspecific and affects several systems, producing high mortality rates in the pediatric population $[1,19]$. In this case report, we found a late beginning of the disease with signs and symptoms similar to splenomegaly, variable thrombocytopenia from hypersplenism [20] and no pulmonary symptoms, which usually are described in these kinds of patients. Symptoms were nonspecific, though they could be frequent in other kinds of diseases and depend on the penetrance of the disease, as seen from the results of the enzymatic test whose results may have low specificity. In addition, there was a lack of family history; all these are useful for diagnosis. Table 2 shows the signs and symptoms of every NP disease type $[3,15]$. 


\section{Cureus}

\begin{tabular}{|c|c|c|c|}
\hline System / Organ & Type A & Type B & Type C \\
\hline $\begin{array}{l}\text { Age of onset, } \\
\text { genotype }\end{array}$ & $\begin{array}{l}\text { Child population (Preschool). } \\
\text { Mean of time to death: } 27 \\
\text { months. Related to SMPD-1 gene } \\
\text { with p.R498L, p.L304P y } \\
\text { p.P333Sfs, } 52 \text { variants ASM } \\
\text { deficiency }\end{array}$ & $\begin{array}{l}\text { Child population/adulthood survival to } \\
\text { adult age, death due to a progressive } \\
\text { liver or pulmonary disease. Related to } \\
\text { p. } \Delta \text { R610, p.P323A, p.P330R y p.W393G } \\
\text { variants. ASM deficiency }\end{array}$ & $\begin{array}{l}\text { Child population/adulthood. Related } \\
\text { to NPC1 y NPC2 genes, more than } \\
352 \text { mutations have been reported. } \\
\text { Alteration of LDL transportation }\end{array}$ \\
\hline $\begin{array}{l}\text { Central nervous } \\
\text { system }\end{array}$ & $\begin{array}{l}\text { Mild hypotony, loss of deep } \\
\text { tendon reflexes: dysphagia. } \\
\text { Progressive neurodegeneration. }\end{array}$ & No neurodegeneration & $\begin{array}{l}\text { Slow neuronal degeneration (ataxia, } \\
\text { dystonia, and cognitive impairment). } \\
\text { Psychomotor delay, central } \\
\text { hypotony, hypoacusia. Progressive } \\
\text { dysarthria. Seizures crisis }\end{array}$ \\
\hline Ophthalmologic & $\begin{array}{l}30 \% \text { of patients have a cherry red } \\
\text { spot in the retina from } 6 \text { months } \\
\text { of age }\end{array}$ & $\begin{array}{l}\text { Ocular anomalies due to neuronal } \\
\text { storage in some patients in the absence } \\
\text { of neurologic disease }\end{array}$ & $\begin{array}{l}\text { Supranuclear paralysis of vertical } \\
\text { gaze }\end{array}$ \\
\hline Gastrointestinal & $\begin{array}{l}\text { Hepatosplenomegaly from } 3 \\
\text { months of age. Jaundice emesis }\end{array}$ & $\begin{array}{l}\text { Hepatosplenomegaly. Usually, } \\
\text { splenomegaly onset is before } \\
\text { hepatomegaly Portal hypertension, } \\
\text { cirrhosis, ascites. Abnormal liver } \\
\text { function test. Diarrhea }\end{array}$ & $\begin{array}{l}\text { Hydrops hepatosplenomegaly. } \\
\text { Persistent fetal ascites. Prolonged } \\
\text { cholestasis. Youth and adult with } \\
\text { only splenomegaly }\end{array}$ \\
\hline Pulmonary & $\begin{array}{l}\text { Frequent and recurrent } \\
\text { respiratory infections: Aspiration } \\
\text { pneumonia Interstitial lung } \\
\text { disease }\end{array}$ & $\begin{array}{l}\text { Interstitial lung disease. Restrictive } \\
\text { features }\end{array}$ & Respiratory insufficiency \\
\hline Cardiac & No abnormalities & $\begin{array}{l}\text { Valvular heart disease. Mixed } \\
\text { dyslipidemia. Coronary disease in early } \\
\text { onset. }\end{array}$ & No heart involvement \\
\hline Musculoskeletal & $\begin{array}{l}\text { aelayed growth with low weight } \\
\text { and height, producing slow } \\
\text { skeletal maturation }\end{array}$ & $\begin{array}{l}\text { with a high risk of pathologic fractures. } \\
\text { Delayed bone maturation. Osteoporosis }\end{array}$ & No musculoskeletal involvement \\
\hline Hematological & $\begin{array}{l}\text { No hematological involvement or } \\
\text { mild thrombocytopenia }\end{array}$ & $\begin{array}{l}\text { Thrombocytopenia with a tendency of } \\
\text { bleeding }\end{array}$ & No hematological involvement \\
\hline Treatment & $\begin{array}{l}\text { Liver transplantation } \\
\text { (controversial) support }\end{array}$ & $\begin{array}{l}\text { Bone marrow transplantation } \\
\text { (controversial) support }\end{array}$ & Miglustat (controversial) \\
\hline
\end{tabular}

\section{TABLE 2: Signs, symptoms and other features of every Niemann-Pick disease type}

ASM: acid sphingomyelinase; LDL: low-density lipoprotein

Genetic sequencing is the gold standard diagnostic test for the confirmation of NP disease. In this case, there was SMPD1 gene mutation information, which later confirmed the presence of NP cells in the bone marrow aspiration sample [17]. It is necessary to determine the enzymatic activity or proteins of acid sphingomyelinase (ASM) in leukocytes from peripheral blood, found in low levels $(1 \%-0 \%)$ in patients with NP disease types A or B or by a fibroblast culture or lymphoblast for NP type C [6,19]. In this patient, an alteration in lipid metabolism was evident, and in the pathologic report of the spleen, there were macrophages with a wide and foamy cytoplasm, being negative for neoplastic and infectious findings, which was consistent with literature descriptions [16]. The beta-glycosidase reports showed an enzyme activity reduction. Nevertheless, it may have overexpression with high values like in the case herein. These results might be explained by the hereditary variation in each different case.

Among the therapeutic options, liver transplantation in the infant population for type $\mathrm{A}$, and cordon cells or bone marrow transplantation for type B have been demonstrated. For type C, miglustat is demonstrated to improve the neurologic symptoms via the inhibition of glycosphingolipids biosynthesis, thereby reducing lipid storage, which has been demonstrated in clinical trials, showing improvement in symptoms in patients with mild to moderate neurological, psychiatric, or cognitive manifestations [20]. Although there is no specific treatment in our case, given the type of disease and pharmacologic indication, it should be important for health professionals to recognize this metabolic disorder and use a multidisciplinary 
approach, focusing on growth and developing assessments of nutritional state, lung functional status, and abdominal and neurologic surveillance. Furthermore, genetic counseling should be another factor taken into consideration, as despite its recessive autosomal features, each live birth has a $25 \%$ probability of being affected and 50\% can be a carrier [20]. Pre-natal assessment tools are available for sphingomyelinase activity, which may be measurable from fibroblast and amniotic liquid or by a gene and molecular test [6].

\section{Conclusions}

In conclusion, these types of diseases have a low frequency in the population, but it is not known whether it is a non-disease occurrence or whether it is a missed diagnosis. Considering how rare these storage diseases are, a differential diagnosis should be considered when other diagnosis options with similar symptoms and signs as splenomegaly and thrombocytopenia have been ruled out. Lastly, a neuropsychological follow-up should be made due to the frequency of complications among these patients.

\section{Additional Information \\ Disclosures}

Human subjects: Consent was obtained by all participants in this study. Institutional Ethics Committee issued approval N/A. Institutional Ethics Committee approved Case reports publications just in case of the informed consent is given and signed by a patient. In this case, the patient provided informed consent and signed, keeping safe the confidentiality, and avoiding publishing the identification information of the patient. Conflicts of interest: In compliance with the ICMJE uniform disclosure form, all authors declare the following: Payment/services info: All authors have declared that no financial support was received from any organization for the submitted work. Financial relationships: All authors have declared that they have no financial relationships at present or within the previous three years with any organizations that might have an interest in the submitted work. Other relationships: All authors have declared that there are no other relationships or activities that could appear to have influenced the submitted work.

\section{References}

1. García-Diaz JD, Mesa-Latorre JM, Corps-Fernandez D, Valbuena-Parra A: Enfermedades por depósito lisosomal [Article in Spanish]. Medicine. 2016, 12:1072-1081. 10.1016/j.med.2016.09.020

2. Villamandos García D, Santos-Lozano A: Enfermedad de Niemann-Pick: un enfoque global [Article in Spanish]. ENE. 2014, 8:

3. McGovern MM, Dionisi C, Giugliani R, et al.: Consensus recommendation for a diagnostic guideline for acid sphingomyelinase deficiency. Genet Med. 2017, 19:967-974. 10.1038/gim.2017.7

4. Vanier MT, Millat G: Niemann-Pick disease type C. Clin Genet. 2003, 64:269-281. 10.1034/j.13990004.2003.00147.x

5. Yanuzzi LA: Distrofias Coriorretinianas Hereditarias [Book in Spanish]. Elsevier, España; 2011. 10.1016/j.oftal.2011.07.009

6. Zarco-Román J, García-Pérez AN, Andrade-Aldama P, Carbajal-Rodríguez L, Rodríguez-Herrera R: Enfermedad de Niemann-Pick tipo B. Estudio de tres casos y revisión de la literatura [Article in Spanish] . Acta Pediatr Mex. 2014, 35:30-37.

7. Lario A, de Miguel C, Ojeda E, Gil S, Coll MJ, Alfonso P: New mutation in a young woman diagnosed with Niemann-Pick disease type C [Article in Spanish]. Medicina Clínica. 2016, 146:494-496. 10.1016/j.medcle.2016.07.003

8. Public summary of positive opinion for orphan designation of recombinant human acid sphingomyelinase for the treatment of Niemann-Pick disease, type B. (2009). Accessed: May 28, 2019:

https://www.ema.europa.eu/en/documents/orphan-designation/eu/3/01/056-public-summary-positiveopinion-orphan-designat....

9. Instituto Nacional de Vigilancia de Medicamentos y Alimentos [Article in Spanish] . (2009). Accessed: May 28, 2019: https://www.invima.gov.co/conformacion-de-las-salas-especializadas/sala-especializada-demedicamentos-y-productos-bio....

10. Arcila MLP: Current situation of orphan diseases in Colombia 2017 [Article in Spanish] . Rev Ces Derecho. 2017, 8:231-241.

11. Congreso de la Republica de Colombia [Article in Spanish] . (2010). Accessed: May 28, 2019: https://www.minsalud.gov.co/sites/rid/Lists/BibliotecaDigital/RIDE/DE/DIJ/ley-1392-de-2010.pdf.

12. Ministerio de Salud y Protección Social. Enfermedades Huérfanas [Article in Spanish] . (2013). Accessed: May 28, 2019: https://www.minsalud.gov.co/salud/publica/PENT/Paginas/enfermedades-huerfanas.aspx.

13. Sistema Integral de Informacion de la proteccion social. Número de pacientes por tipo de Enfermedad [Article in Spanish]. (2013). Accessed: May 28, 2019: https://app.powerbi.com/view? r=eyJrIjoiMDM0YzE1MmQtOThiZi00MDI1LThiY2EtYjBjMjIwNzZhYTdiIiwidCI6ImJIY2Y5MTM0LWExNjctNG....

14. Grummer-Strawn LM, Li R, Perrine CG, Scanlon KS, Fein SB: Infant feeding and long-term outcomes: results from the year 6 follow-up of children in the Infant Feeding Practices Study II. Pediatrics. 2014, 134:1-3. 10.1542/peds.2014-0646B

15. Pardo Echeverría LC, Arrieta Violet LA, Seabra Souza FT: Diagnóstico bioquímico positivo en pacientes con sospecha clínica de Niemann Pick C [Article in Spanish]. Cienc en Desarro. 2016, 7:31-41.

16. Shumnalieva R, Monov S, Shoumnalieva-Ivanova V, Rashkov R: Adult Niemann-Pick disease type B with myositis ossificans: a case report. Acta Reumatol Port. 2016, 41:260-264.

17. Abraçado-Amara IS, Lameira de Medeiros Z, Pereira-Moia L, et al.: Informe de caso: enfermedad de Niemann-Pick con manifestaciones de insuficiencia hepática [Article in Spanish]. Rev Pan-Arnaz Saude. 2010, 1:129-132. 


\section{Cureus}

18. Kliegman RM, Stanton BF, St Geme JW, Schor NF, Behrman RE: Tratado de Pediatría [Book in Spanish] . Elsevier, Barcelona-España; 2016.

19. McGovern MM, Desnick RJ: Lipidosis (enfermedades por depósito lisosómico). Tratado de Pediatría [Book in Spanish]. 2016 (ed): Elsevier, 744-745;

20. Patterson MC, Vecchio D, Prady H, Abel L, Wraith JE: Miglustat for treatment of Niemann-Pick C disease: a randomised controlled study. Lancet Neurol. 2007, 6:765-772. 10.1016/S1474-4422(07)70194-1 